\title{
PENGGUNAAN SUPERVISI KLINIS UNTUK MENINGKATKAN KEMAMPUAN GURU DALAM PEMBELAJARAN DI SD SINDET KECAMATAN JETIS KABUPATEN BANTUL TAHUN PELAJARAN 2019/2020
}

\author{
Heny Rismiati \\ SD Sindet Jetis Bantul \\ henyrismiati@gmail.com
}

\begin{abstract}
Abstrak: Tujuan penelitian tindakan Sekolah ini adalah: 1) Meningkatkan kemampuan guru dalam pembelajaran melalui supervise klinis di SD Sindet Kecamatan Jetis Kabupaten Bantul. 2) Menerapkan langkah-langkah bimbingan/supervisi klinis dalam meningkatkan kemampuan pembelajaran oleh guru. Metode Penelitian Tindakan Sekolah terdiri dari dua siklus, Dimana dalam prosedur setiap siklus terdiri dari perencanaan, tindakan, observasi, dan refleksi. Tehnik pengumpulan data dalam penelitian ini menggunakan observasi, pengamatan, dan wawancara. Subjek penelitian adalah guru-guru SD Sindet Kecamatan Jetis Berjumlah 11 orang guru. Instrumen penelitian yang digunakan antara lain: 1) Lembar observasi merencanakan kemampuan merencanakan pembelajaran (RPP), 2) Lembar observasi melaksanakan pembelajaran (PBM), (3). Lembar Observasi Penilaian terhadap proses pembelajaran. Hasil Penelitian menunjukkan bahwa terjadi peningkatan kemampuan guru dalam pembelajaran melalui supervisi klinis semester 1 tahun pelajaran 2019/2020 pada SD Sindet Kecamatan Jetis. Pada Siklus I hasil penilaian dalam menyusun RPP mencapai 70\%, pelaksanaan PBM mencapai 82\%, dan Penilaian Pembelajaran mencapai 79\%. Di Siklus II Penyusunan RPP mencapai 82\%, PBM mencapai 85\%, dan Penilaian Pembelajaran mencapai 84\%. Berdasarkan hasil penelitian Tindakan sekolah yang terkait dengan penggunaan supervisi klinis untuk meningkatkan kemampuan guru dalam pembelajaran dapat diterik kesimpulan mengalami peningkatan atau meningkat.
\end{abstract}

Kata kunci: supervisi klinis, kemampuan guru, pembelajaran

\section{THE USAGE OF CLINICAL SUPERVISION TO IMPROVE TEACHER'S ABILITY IN LEARNING AT SINDET ELEMENTARY SCHOOL, JETIS DISTRICT, BANTUL REGENCY 2019/2020 ACADEMIC YEAR}

\begin{abstract}
The objectives of this school action research are: 1) Improving the ability of teachers in learning through clinical supervision in Jetis Sindet Elementary School, Bantul District, 2) Implementing clinical guidance/supervision steps in enhancing teacher learning abilities. The School Action Research method consists of two cycles. In the procedure each cycle consists of planning, action, observation, and reflection. Data collection techniques in this study used observations, and interviews. The subjects were 11 teachers of Sindet Elementary School, Jetis District, Bantul Regency. The research instruments used include; 1) Observation sheet ability to compile a Lesson Plan (RPP). 2) Learning implementation observation sheet $(P B M) .3)$ Observation Sheet Assessment of the learning process. The results showed that there was an increase in the ability of teachers in learning through clinical supervision in semester 1 of the 2019/2020 school year at SD SindetJetis District. In the first cycle, the results of research in compiling lesson plans reached $70 \%$, PBM implementation reached $82 \%$, and learning assessments reached $79 \%$. In the second cycle compilation of lesson plans increased to $82 \%$, PBM reached $85 \%$, and learning assessments reached $84 \%$. Based on the results of school action research related to the use of clinical supervision to improve the ability of teachers in learning, conclusions can be improved.

Keywords: clinical supervision, teacher ability, learning

\section{PENDAHULUAN}

Pembelajaran bermutu di sekolah merupakan kewajiban bagi guru secara umum, namun demikian hal ini masih belum dilakukan dengan maksimal oleh guru, dan mereka belum banyak kreatif menggunakan model-model pembelajara maupun teknik-teknik pendekatan yang baru. Seolah-olah guru hanya menyampaikan materi pelajaran saja, kurang

kontrol terhadap kondisi siswa saat pembelajaran berlangsung. Guru-guru di kelas rata-rata belum memberdayakan strategi gaya dan seni mengajar yang maju. Di SD Sindet Kecamatan Jetis Kabupaten Bantul, berdasarkan hasil supervisi rutin peneliti sebagai Kepala sekolah di SD Sindet ternyata menemukan sebagian besar guru masih melaksanakan pembelajaran yang tradisional, dimana guru
\end{abstract}


dalam melaksanakan pembelajaran tanpa menggunakan RPP yang dibuat sendiri, mereka cenderung menggunakan RPP cetakan yang ada dan belum melaksanakan pembelajaran dengan baik. Guru masih melaksanakan pembelajaran dengan metode ceramah murni belum rutin bervariasi, maupun belum menggunakan alat peraga, dan tampaknya guru masih sebagai penyampai materi bentuk klasikal, maupun belum menggunakan alat peraga, dan tampaknya guru masih sebagai penyampai materi bentuk klasikal, belum banyak melakukan pembelajaran yang kreatif, yang dapat melatih mandiri dan tanggungjawab para peserta didik.

Bimbingan yang telah dilaksanakan oleh peneliti dari sejumlah guru kelas yang ada di SD Sindet sebanyak 11 orang guru yang terdiri dari guru kelas I samapai dengan VI, ternyata hanya ada 4 orang guru atau $36 \%$ yang telah melaksanakan pembelajaran dengan baik, jadi masih ada 7 atau $64 \%$ guru belum mampu melaksanakan pembelajaran baik secara nyata bahwa guru kelas masih melaksanakan pembelajaran yang biasa-biasa saja. Pembelajaran yang dilakukan hanya menggunakan metode ceramah tanpa ada variasi dan kurang memanfaatkan peluang, membentuk kelompok-kelompok kecil di kelasnya.

Guru dan Kepala sekolah merupakan komponen utama yang harus memberdayakan diri agar dalam hal ini peneliti sebagai kepala sekolah berupaya melakukan bimbingan klinis terutama guru kelas. Dalam penelitian ini ada dua masalah pokok yang akan diteliti, yaitu pertama masalah kegiatan guru mengajar dan yang kedua kemampuan guru dalam menyusun RPP yang sesuai denagn standar proses menurut Permendikbud no 41 tahun 2007. Diharapkan para guru mampu melaksanakan pembelajaran secara maksimal.

Supervisi klinis yang dilakukan Kepala sekolah sebagai peneliti akan berupaya mempengaruhi guru selalu termotivasi, dan mereka agar selalu merasa sebagai agen pembelajaran yang sesuai dengan ketentuan. John J. Bolla menyimpulkan bahwa supervisi klinis adalah suatu proses bimbingan yang bertujuan untuk membantu pengembangan profesional guru calon guru, khususnya dalam penampilan mengajar, berdasarkan observasi dan analisis data secara detail dan objektif sebagai pegangan untuk perubahan tingkah laku mengajar tertentu (Ngalim Purwanto, 2009: 91).
Berdasarkan uraian di atas dapat dirumuskan masalah sebagai berikut: 1). Bagaimana peningkatan ketrampilan Proses Belajar Mengajar guru melalui Supervisi Klinis di SD Sindet Semester 1 tahun pelajaran 2019/2020? 2). Bagaimana penerapan Supervisi Klinis untuk meningkatkan kemampuan guru dalam pembelajaran di SD Sindet Semester 1 tahun pelajaran 2019/2020? Tujuan penelitian tindakan Sekolah ini adalah: 1) Meningkatkan kemampuan guru dalam pembelajaran melalui supervisi klinis di SD Sindet Kecamatan Jetis Kabupaten Bantul Semester 1 Tahun Pelajaran 2019/2020. 2) Menerapkan langkah-langkah bimbingan/ supervisi klinis dalam meningkatkan kemampuan pembelajaran oleh guru.

\section{METODE PENELITIAN Jenis Penelitian}

Penelitian ini merupakan penelitian tindakan sekolah yang dilakukan secara kolaborasi dan partisipatif. Artinya peneliti tidak melakukan penelitian sendiri, namun berkolaborasi atau bekerja sama dengan guru kelas I sampai dengan kelas VI di SD Sindet Kecamatan Jetis, Bantul, Yogyakarta. Secara partisipatif guru dan kepala sekolah bersama sama melakukan peneliti ini langkah demi langkah. Penelitian ini menekankan pada peningkatan pembelajaran yaitu kegiatan guru dalam melakukan kegiatan belajar mengajar.

\section{Waktu dan Tempat Penelitian}

Waktu pelaksanaan direncanakan selama 3 bulan dari bulan Agustus sampai dengan bulan November 2019. Waktu Penelitian ini dilaksanakan dengan jadwal sebagai berikut: Siklus 1 dilaksanakan tanggal 30 Agustus 2019 sampai dengan 4 Oktober 2019, Siklus 2 dilaksanakan pada tanggal 5 Oktober sampai dengan 15 November 2019.

Lokasi Penelitian di SD Sindet merupakan salah satu sekolah pemerintah yang berada di wilayah desa Trimulyo Kecamatan Jetis Kabupaten Bantul yang secara geografis terletak di daerah pegunungan tidak terlalu jauh dari kota. Jumlah siswa pada tahu 2019 ini ada 257 siswa dibagi menjadi 11 rombongan belajar.

\section{Subjek Penelitian}

Subjek penelitian adalah guru-guru SD Sindet Kecamatan Jetis Berjumlah 11 orang guru, dengan jumlah guru laki-laki 4 orang dan jumlah guru perempuan 7 orang. 


\section{Prosedur Penelitian}

Dalam penelitian ini menggunakan model spiral dari Kemmis dan Taggart yang terdiri dari dua siklus, dan masing-masing siklus menggunakan empat komponen tindakan yaitu perencanaan, tindakan, observasi dan refleksi dalam satu spiral yang saling terkait.

Data, Instrumen, dan Teknik Pengumpulan data

Teknik yang digunakan untuk mengumpulkan data meliputi observasi, wawancara, dan dokumentasi yang masingmasing: 1) Membuat instrument rencana supervisi/ program supervisi, 2) instrumen pelaksanaan supervisi (Lembar pelaksanaan Supervisi), 3) Instrumen supervisi penilaian (Lembar observasi penilaian Proses pembelajaran) untuk mengukur kemampuan guru dalam menyusun RPP, melaksanakan PBM, dan Penilaian Proses pembelajaran. Adapun setiap Siklus langkah-langkahnya sebagai berikut: 1) Perencanaan, 2) pelaksanaan, 3) Observasi, 4) Refleksi.

\section{HASIL DAN PEMBAHASAN Siklus 1}

Hasil tindakan yang dilakukan oleh peneliti terdiri dari 2 (dua) siklus. Hasil Observasi Penilaian RPP guru yang dilakukan oleh peneliti diperoleh hasil rata-rata hasil penilaian RPP di Siklus I penelitian dan telaah RPP keadaan RPP dari guru yang terkumpul dari guru kelas dari kelas I sampai dengan VI menunjukkan Nilai sebesar 856 dengan ratarata mencapai 78 dengan kriteria Cukup.

Tabel .1.1. Rekapitulasi Hasil Penilaian RPP Siklus I

\begin{tabular}{|c|c|c|c|c|}
\hline No & Kriteria nilai & Rentang nilai & $\mathrm{F}$ & $\%$ \\
\hline 1 & $\mathrm{~A}=$ Amat Baik & $90-100$ & & \\
\hline 2 & B = Baik & $80-90$ & 4 & $36 \%$ \\
\hline 3 & $\mathrm{C}=$ Cukup & $70-80$ & 7 & $64 \%$ \\
\hline 4 & $\mathrm{~K}=$ Kurang & $0-70$ & - & \\
\hline \multicolumn{3}{|c|}{ Jumlah } & 11 & $100 \%$ \\
\hline
\end{tabular}

Berdasarkan penilaian RPP pada Siklus I dapat diketahui bahwa guru yang mempunyai penilaian RPP yang baik ada 4 orang atau mencapai $36 \%$. Selain itu dapat dketahui bahwa rata-rata penilaian RPP guru pada siklus I menunjukkan nilai 78 atau masuk dalam kategori Cukup ada 6 orang guru, dan ada 2 orang guru mempunyai nilai kurang. Nilai baik (B) ada 3 orang guru. RPP guru di Siklus I diperoleh nilai skor rata-rata 78 dengan predikat Cukup (C), berarti lebih baik dari kriteria RPP sebelum dilakukan penelitian yang mencapai nilai rata-rata 74 .
Tabel. 1.2. Rekapitulasi PBM Guru Siklus I

\begin{tabular}{|c|c|c|c|c|}
\hline No & Kriteria nilai & Rentang nilai & $\mathrm{F}$ & $\%$ \\
\hline 1 & $\mathrm{~A}=$ amat baik & $90-100$ & - & \\
\hline 2 & $\mathrm{~B}=$ baik & $80-90$ & 7 & $64 \%$ \\
\hline 3 & $\mathrm{C}=$ cukup & $70-80$ & 4 & $36 \%$ \\
\hline 4 & $\mathrm{~K}=$ kurang & $0-70$ & - & \\
\hline \multicolumn{3}{|c|}{ Jumlah } & 11 & $100 \%$ \\
\hline
\end{tabular}

Penilaian PBM guru siklus I dapat diketahui bahwa guru yang mempunyai penilaian PBM yang baik ada 4 orang atau mencapai $36 \%$, cukup ada 7 orang atau mencapai $64 \%$ dari total guru yang diamati. Selain itu dapat dketahui bahwa rata-rata penilaian PBM guru pada kondisi awal (pra siklus) menunjukkan nilai 79 atau masuk dalam kategori Cukup. Nilai mencapai sebesar 855 dengan rata-rata nilai 78 dengan kriteria Cukup.

Tabel.1.3. Rekapitulasi Penilaian Proses Hasil Pembelajaran

\begin{tabular}{clccc}
\hline No & Kriteria nilai & Rentang nilai & F & $\%$ \\
\hline 1 & A = amat baik & $90-100$ & & \\
2 & B = baik & $80-90$ & 4 & $36 \%$ \\
3 & C = cukup & $70-80$ & 7 & $64 \%$ \\
4 & K = kurang & $0-70$ & - & - \\
\hline \multicolumn{3}{c}{ Jumlah } & 11 & $100 \%$ \\
\hline
\end{tabular}

Berdasarkan Penilaian Proses Belajar Mengajar guru pada kondisi Siklus I dapat diketahui bahwa guru yang mempunyai penilaian proses hasil belajar yang baik ada 6 orang atau 55\%, cukup ada 4 orang atau $36 \%$ dari total guru yang diamati. Sedangkan nilai kurang ada 1 orang guru atau 9,5\%. Rata-rata penilaian proses hasil belajar guru pada kondisi Siklus I menunjukkan nilai 78 atau masuk kategori Cukup. Nilai mencapai sebesar 896 dengan rata-rata nilai 81 dengan kriteria Baik.

Tabel.1.4. Rekapitulasi Respon Guru terhadap

Pelaksanaan Supervisi Klinis Siklus I

\begin{tabular}{|c|c|c|c|c|}
\hline No & Kriteria nilai & Rentang nilai & $\mathrm{F}$ & $\%$ \\
\hline 1 & $\mathrm{~A}=$ amat baik & $90-100$ & & \\
\hline 2 & B = baik & $80-90$ & 8 & $73 \%$ \\
\hline 3 & $\mathrm{C}=$ cukup & $70-80$ & 3 & $27 \%$ \\
\hline 4 & $\mathrm{~K}=$ kurang & $0-70$ & - & - \\
\hline \multicolumn{3}{|c|}{ Jumlah } & 11 & $100 \%$ \\
\hline
\end{tabular}

Berdasarkan hasil Respon Guru terhadap Pelaksanaan Supervisi Klinis di Siklus I dapat diketahui bahwa guru yang mempunyai Respon terhadap Pelaksanaan Supervisi Klinis yang baik ada 8 orang atau $73 \%$, cukup ada 3 orang atau $27 \%$ dari total guru yang diamati. Selain itu dapat dketahui bahwa rata-rata respon guru terhadap Pelaksanaan Supervisi Klinis pada kondisi Siklus I menunjukkan nilai 81 atau masuk kategori Baik. 


\section{Siklus II}

Hasil Observasi Penilaian RPP guru yang dilakukan oleh peneliti di siklus II diperoleh hasil rata- rata sebesar 941 dengan rata-rata mencapai 85 dengan kriteria Baik.

Tabel .1.5. Rekapitulasi Hasil Penilaian RPP Siklus II

\begin{tabular}{|c|c|c|c|c|}
\hline No & Kriteria nilai & Rentang nilai & $\mathrm{F}$ & $\%$ \\
\hline 1 & $\mathrm{~A}=$ amat baik & $90-100$ & - & - \\
\hline 2 & $\mathrm{~B}=$ baik & $80-90$ & 9 & $82 \%$ \\
\hline 3 & $\mathrm{C}=$ cukup & $70-80$ & 2 & $18 \%$ \\
\hline 4 & $\mathrm{~K}=$ kurang & $0-70$ & - & \\
\hline \multicolumn{3}{|c|}{ Jumlah } & 11 & $100 \%$ \\
\hline
\end{tabular}

Berdasarkan penilaian RPP pada Siklus II dapat diketahui bahwa guru yang mempunyai penilaian RPP yang baik ada 9 orang atau mencapai $82 \%$.

Tabel.1.6. Rekapitulasi PBM Guru Siklus II

\begin{tabular}{|c|c|c|c|c|}
\hline No & Kriteria nilai & Rentang nilai & $\mathrm{F}$ & $\%$ \\
\hline 1 & $\mathrm{~A}=$ amat baik & $90-100$ & - & \\
\hline 2 & $\mathrm{~B}=$ baik & $80-90$ & 10 & $91 \%$ \\
\hline 3 & $\mathrm{C}=$ cukup & $70-80$ & 1 & $9 \%$ \\
\hline 4 & $\mathrm{~K}=$ kurang & $0-70$ & - & \\
\hline \multicolumn{3}{|c|}{ Jumlah } & 11 & $100 \%$ \\
\hline
\end{tabular}

Penilaian PBM guru siklus II dapat diketahui bahwa guru yang mempunyai penilaian PBM yang baik ada 10 orang atau mencapai $91 \%$, cukup ada 1 orang atau mencapai $9 \%$ dari total guru yang diamati. Sedangkan tidak ada guru dengan nilai kurang.

Tabel.1.7. Rekapitulasi Penilaian Hasil Belajar dari Guru

\begin{tabular}{|c|c|c|c|c|}
\hline No & Kriteria nilai & Rentang nilai & $\mathrm{F}$ & $\%$ \\
\hline 1 & $\mathrm{~A}=$ amat baik & $90-100$ & & \\
\hline 2 & $\mathrm{~B}=$ baik & $80-90$ & 9 & $82 \%$ \\
\hline 3 & $\mathrm{C}=$ cukup & $70-80$ & 2 & $18 \%$ \\
\hline 4 & $\mathrm{~K}=$ kurang & $0-70$ & - & - \\
\hline \multicolumn{3}{|c|}{ Jumlah } & 11 & $100 \%$ \\
\hline
\end{tabular}

Berdasarkan Penilaian Proses Belajar Mengajar guru pada kondisi Siklus II dapat diketahui bahwa guru yang mempunyai penilaian proses hasil belajar yang baik ada 9 orang atau mencapai $82 \%$, cukup ada 2 orang atau mencapai $18 \%$ dari total guru yang diamati. Sedangkan nilai kurang tidak ada. Selain itu dapat dketahui bahwa rata-rata penilaian proses hasil belajar guru pada kondisi Siklus I menunjukkan nilai 78 atau masuk dalam kategori Cukup. Hasil Penilaian Respon Guru terhadap pelaksanaan Supervisi klinis Siklus II.
Tabel.1.8. Rekapitulasi Respon Guru terhadap

Pelaksanaan Supervisi Klinis Siklus II

\begin{tabular}{|c|c|c|c|c|}
\hline No & Kriteria nilai & Rentang nilai & $\mathrm{F}$ & $\%$ \\
\hline 1 & $\mathrm{~A}=$ amat baik & $90-100$ & - & - \\
\hline 2 & $\mathrm{~B}=$ baik & $80-90$ & 11 & $100 \%$ \\
\hline 3 & $\mathrm{C}=$ cukup & $70-80$ & - & - \\
\hline 4 & $\mathrm{~K}=$ kurang & $0-70$ & - & - \\
\hline \multicolumn{3}{|c|}{ Jumlah } & 11 & $100 \%$ \\
\hline
\end{tabular}

Skor rata-rata penilaian dari pra siklus RPP mencapai 75 atau cukup, di siklus I rata-rata mencapai 78 dengan kriteria cukup dan di Siklus II rata-rata mencapai 85 atau dengan kriteria B (Baik). Hasil Penilaian PBM Pra Siklus rata-rata mencapai 73 atau cukup, siklus I mencapai ratarata 78 dengan krietria Cukup, siklus II rata-rata 83 atau dengan kriteria Baik.

Pembahasan Pra Siklus, Siklus I dan Siklus II. Hasil Penilaian untuk hasil penilaian RPP guru pada Pra Siklus, Siklus I dan Siklus II adalah sebagai berikut: untuk di awal siklus diperoleh nilai rata-rata 56, siklus I 70 dan siklud II 82. Di siklus I masih di bawah kriteria keberhasilan yaitu 82 , sedangkan di siklus II sudah di atas indikator keberhasilan yaitu mencapai nilai rata-rata 82 .

Tabel.1.9. Peningkatan Penyusunan RPP

\begin{tabular}{lccc}
\hline No $\quad \sum$ Guru & 4wal Siklus & Siklus I Siklus II \\
\hline 1. & 11 guru & $56 \%$ & $70 \%$ \\
\hline
\end{tabular}

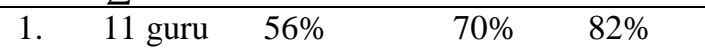

Data pada tabel di atas dapat ditarik kesimpulan bahwa penyusunan RPP guru kelas I sampai dengan VI meningkat bila digambarkan dalam grafik, prosentase RPP guru dapat dilihat pada grafik di bawah ini:

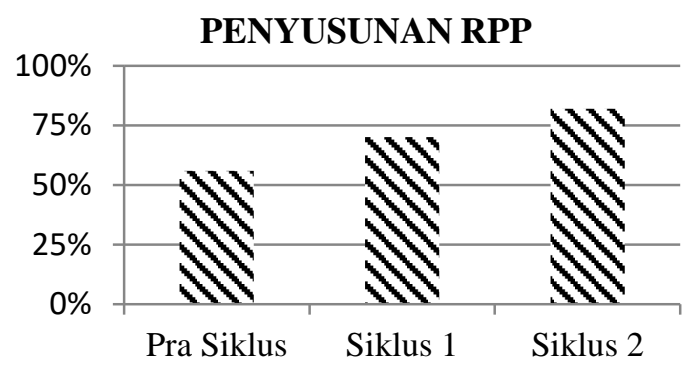

Gambar.1.1Peningkatan Penyusunan RPP

Hasil penilaian PBM guru pada awal siklus, siklus I dan siklus II adalah sebagai berikut: rata-rata di siklus I dan siklus II mencapai 82 atau $82 \%$, siklus II mencapai 85 atau $85 \%$.

Tabel.1.10. Perbandingan Nilai PBM guru Pra Siklus, siklus I dan siklus II

\begin{tabular}{|c|c|c|c|}
\hline No & $\sum$ Guru & Awal Siklus & Siklus I Siklus II \\
\hline 1. & 11 guru & $75 \%$ & $82 \% \quad 85 \%$ \\
\hline
\end{tabular}


Dari data perbandingan pada tabel di atas, maka dapat ditarik kesimpulan bahwa pelaksanaan PBM guru kelas I samapai dengan VI mengalami peningkatan. Bila digambarkan dalam grafik prosentase pelaksanaan PBM sebagai berikut

\section{PENINGKATAN PBM}

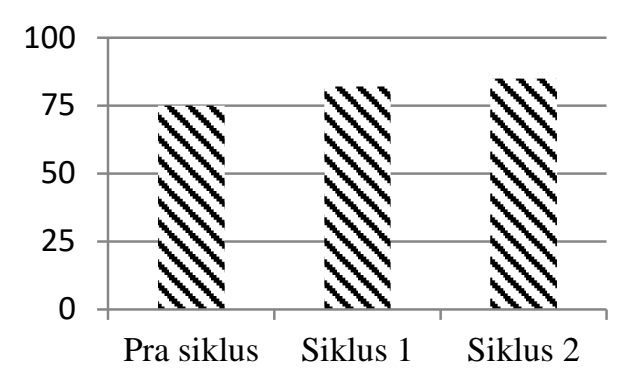

Gambar.1.2. Grafik peningkatan PBM

Hasil penilaian Pembelajaran oleh guru pada awal siklus, siklus I rata-rata $64 \%$, siklus I rata-rata mencapai $80 \%$ dan di siklus II mencapai $84 \%$.

Tabel.1.11 Perbandingan Penilaian Pembelajarann oleh guru guru Pra Siklus, siklus I dan siklus II

\begin{tabular}{|c|c|c|c|c|}
\hline No & $\sum$ Guru & Awal Siklus & Siklus I & Siklus II \\
\hline 1. & 11 guru & $64 \%$ & $79 \%$ & $84 \%$ \\
\hline
\end{tabular}

Dari data perbandingan pada tabel di atas, maka dapat ditarik kesimpulan bahwa pelaksanaan Penilaian Pembelajarann oleh guru kelas I samapai dengan VI mengalami peningkatan. Bila digambarkan dalam grafik prosentase pelaksanaan PBM sebagai berikut:

PENILAIAN PEMBELAJARAN

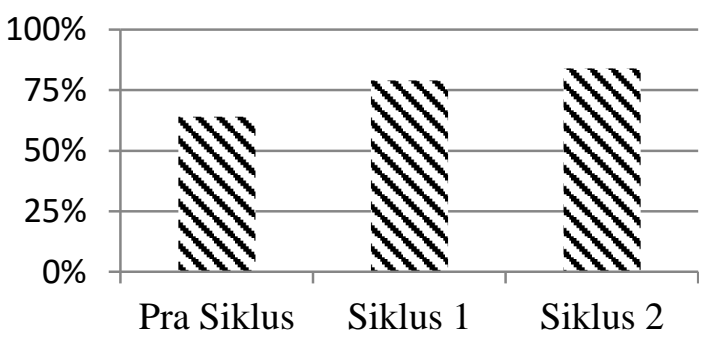

Gambar.1.3 Grafik peningkatan Penilaian Pembelajaran oleh guru

Berdasarkan hasil penilaian Respon guru terhadap pelaksanaan Supervisi klinis pada awal siklus, siklus I rata-rata $75 \%$, siklus I rata-rata mencapai $81 \%$ dan di siklus II mencapai $86 \%$.
Tabel.1.12. Perbandingan Penilaian Respon Guru Pra Siklus, siklus I dan siklus II

\begin{tabular}{|c|c|c|c|c|}
\hline No & $\sum$ Guru & Awal Siklus & Siklus I & Siklus II \\
\hline 1. & 11 guru & $75 \%$ & $81 \%$ & $86 \%$ \\
\hline
\end{tabular}

Dari data perbandingan pada tabel di atas, maka dapat ditarik kesimpulan bahwa pelaksanaan Penilaian Respon Guru terhadap pelaksanaan supervisi klinis mengalami peningkatan. Bila digambarkan dalam grafik prosentase respon guru terhadap pelaksanaan supervisi klinis sebagai berikut:

PENILAIAN PEMBELAJARAN

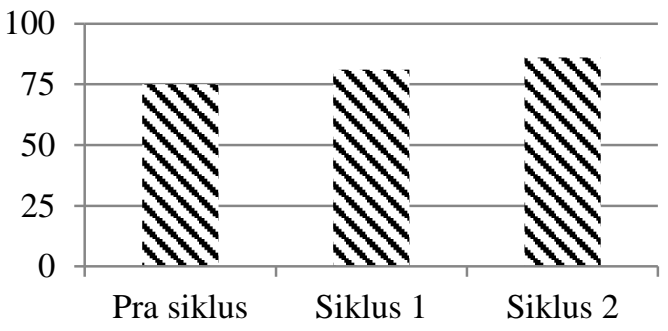

Gambar.4.4 Grafik peningkatan Penilaian Pembelajaran oleh guru

\section{SIMPULAN DAN SARAN}

Berdasarkan hasil penelitian dan pembahasan dalam penelitian ini, maka dapat ditarik kesimpulan sebagai berikut:

1) Cara penerapan peningkatkan kemampuan guru dalam pembelajaran di SD Sindet Semester 1 tahun pelajaran 2019/2020 dengan melalui supervisi klinis.

2) Peningkatkan kemampuan guru dalam pembelajaran di SD Sindet Semester 1 tahun Pelajaran 2019/2020 melalui pelaksanaan supervisi klinis antara lain menyusun Rencana Pelaksanaan Pembelajaran (RPP), Pelaksanaan PBM, dan Penilaian Pembelajaran.

Berdasarkan hasil penelitian, pembahasan, dan kesimpulan yang telah dilakukan, maka saran peneliti sebagai berikut:

1. Pelaksanaan penelitian terjadi adanya kekurangsiapan guru dalam menyusun RPP, dikarenakan guru dalam menyusun RPP hanya disaat diminta oleh kepala sekolah, bukan kesadaran dari guru bahwa menyusun RPP adalah suatu kewajiban sebagai suatu persiapan mengajar dan sebagai acuan dalam guru mengajar. Oleh karena itu saran dari peneliti sebaiknya dalam menyusun RPP disusun melalui workshop ataupun di kegiatan KKG supaya guru dapat menelaah RPP yang baik dan benar. 
2. Dalam PBM masih ada guru yang pelaksanaannya tidak runtut dan tidak sesuai dengan RPP, serta tidak melalui tahapan yang benar. Tidak memakai tahapan Pendahuluan, Inti dan Penutup. Dikarenakan kekurang rutinitas dalam Supervisi kelas oleh kepala sekolah. Dengan peniltian ini diharapkan kegiatan Supervisi Klinis dilaksanakan sesuai dengan program supervisi yang telah dibuat oleh kepala sekolah, jadwal pelaksanaan disosialisasikan kepada guru dan ditindaklanjuti. Dan hasil supervisi disampaikan oleh guru baik secara bersama-sama ataupun secara individual.

\section{DAFTAR PUSTAKA}

Burhanudin, Afid. 2014. Prinsip-prinsip Belajar dan Implimentasinya. Diakses pada tanggal 29 Januari 2016.

Cangelosi. 1995. Merancang Tes Untuk Menilai Prestasi Siswa. Bandung: IT

Djaramah. 2002. Psikologi. Belajar Jakarta: PT. Rineka Cipta.

Ellington. 1984. Tehnologi Pendidikan. Jakarta: Erlangga.
Kemendikbud. 2013. Kurikulum Pedoman Umum Pembelajaran. Jakarta: Kemendikbud.

Kemendikbud. 2013. Panduan Teknis Penyusunan RPP. Jakarta: Kemendikbud.

Mardapi, Djemari. 1999. Pengukuran Penilaian dan Evaluasi. Makalah disampaikan pada Penataran Evaluasi pembelajaran matematika untuk guru tanggal 8- 23 November 1999: di PPPG Matematika Yogyakarta.

Purwanto, Ngalim. 2009. Psikologi Pendidikan. Jakarta: PT. Remaja Rosdakarya.

Rowntree. 1995. Teaching Hrought. New York: Kogan Page London/ Nicholas Publishing.

Sahertian, Piet A. 2000. Konsep Dasar dan Teknik Supervisi Pendidikan dalam rangka Mengembangkan Sumber daya Alam. Jakarta: Rineka Cipta.

Slameto. 2003. Belajar dan Faktor-faktor yang Mempengaruhinya. Jakrta: Rineka Cipta

Usman, Moh. User. 19985. Hakikat Pembelajaran menjadi Guru Profesional. Bandung: Remaja Rosdakarya. 